\title{
Mariel in Contemporary Cuban-American Writing: The Power of Diasporic Postmemory
}

\author{
Raúl Rosales Herrera \\ Drew University, US \\ rrosales@drew.edu
}

Through an exploration of what can now be called Mariel writing across generations, this essay places contemporary second-generation Cuban-American literature written in English in dialogue with the Spanish-language production of "Generación del Mariel" writers who arrived in the U.S. via the 1980 Cuban exodus. Through an analysis of selected works that revisit Mariel and its inherited memories as key components of the Cuban-American story and of Cuban-American identity, this essay illustrates how diasporic subjectivity -in as much as it is conditioned by repeated intergenerational mediations-is also marked by the consequent interrogations of the past and its generational acts of transmission. The essay closely examines the role of Mariel in second-generation Cuban-American texts by Cecilia Rodríguez-Milanés, Chantel Acevedo, and Vanessa Garcia. Concerned with diasporic continuity and futurity, these writers, distanced or not yet born at the time of the exodus, exercise diasporic postmemory and reparative re-memoration to interrogate the silences and stereotypes that have been passed down about Mariel, and in doing so, reframe, revise, and re-voice the history, stories, and memories of Mariel in the diasporic present. These contemporary Mariel narratives, in their broad range and variability, are presented as ultimately sharing common discursive markings and links with "Generación del Mariel" writing, thus contributing to a collective present-day revaluation and reimagining of the exodus and its cultural production across time, languages, and generations.

Keywords: Mariel; Mariel writing; Generación del Mariel; second-generation writing; CubanAmerican writing; diaspora; memory; postmemory; Cecilia Rodríguez-Milanés; Chantel Acevedo; Vanessa Garcia

The longstanding relationship between memory studies and diaspora studies has only intensified in recent years as a result of the increased attention on second- and third-generation cultural production. The diasporic subject-often both the creator and focus of these cultural interventions-increasingly negotiates with memory dynamics, especially its intergenerational transmissions, in order to better contend with the complexities of present-day diasporic reality and experiences. The results often transcend any one individual and ultimately reveal the broader contours of diasporic belonging. As Leo Spitzer so poignantly asserts: memory, as "creatively reconfigured," is pivotal to the construction and affirmation of personal identity in as much as it is also key to the formation of a new collective culture that can serve changed needs (378-379). It is precisely through this symbiotic relationship between the personal and the communal that second-generation cultural texts of memory become such critical tools for the exploration and critical evaluation of a diaspora's intergenerational transmissions and sociocultural "movements."

Cuban-American literature has long been examined though the optics of memory, whether on one end through nostalgic renderings of first-wave writers who fled the island after the Cuban Revolution, or on the other through the postmemory of second-generation writers, often labeled ABCs (American-Born Cubans). In assessing the latter group, Iraida López explains:

After spending their entire lives listening to stories about Cuba in both the private and public domains, it is no wonder that some might consider their imagined Cuba a home, albeit mediated by 
a loaded and ever-present history that is partly their own through personal and collective enclaves of memory. (xxii)

These enclaves provide avenues for repeated present-day negotiations with nostalgia and past history, including its silences and omissions. More concretely, these second-generation Cuban-American writers frequently turn to postmemory, the term popularized by Marianne Hirsch, to carry out their interrogations and reassessments. According to Hirsch: "postmemory characterizes the experience of those who grow up dominated by narratives that preceded their birth, whose own belated stories are displaced by the stories of the previous generation, shaped by traumatic events that can be neither fully understood nor re-created" (Past Lives 420). Moreover, postmemory is typified by a nexus between familial and public transmissions, a dynamic greatly exacerbated for the diasporic subject: "The legacies of the past, transmitted powerfully from parent to child within the family, are always already inflected by broader public and generational stories, images, artifacts, and understandings that together shape identity and identification" (Hirsch and Miller 4). Shaped by the exilic trauma of their ancestors and by the spatial dynamics of a Cuba "so close yet so far away," second-generation Cuban-American writers actively deploy diasporic postmemory through their hybrid identities; they write mainly in English and are part of the complex body of U.S. Latinx literature, albeit while still asserting "a Cuban/hybrid legacy handed down through family stories, myths, religious beliefs, a sense of history, photographs, correspondence, keepsakes, soundscapes, and recipes" (López xii). Inclusive of a varied group that includes figures like Ana Menéndez and Richard Blanco, as well as more recent voices like Derek Palacio and Gabriela García, Cuban-American second-generation writing is rather diverse in its content and approaches, even while broadly sharing discursive characteristics as related to postmemory.

Many second-generation writers employ postmemory to not only challenge what has been passed down by previous generations, but, in doing so, to also disrupt and alter the very components constituting CubanAmerican diasporic history. These writers' critical stance follows in the tradition of others whose works have gone against the grain of mainstream Cuban-American writing, like Dolores Prida, Roberto G. Fernández, and Achy Obejas. From challenging nostalgic transmissions and questioning the existence of a paradisiacal pre-revolutionary Cuba, to having a more nuanced perspective towards Cuban exile politics, second-generation writers share a commonality: they seek to affirm present-day diasporic identity, and resolve that a key avenue to doing so involves shaking up the inherited memories that are so critical to the shaping of identity in the first place. As Hirsch and Miller emphasize regarding diaspora and postmemory: "In the language of diaspora, originary homelands are not simply there to be recovered: already multiply interconnected with other places, they are further transformed by the ravages of time, transfigured through the lenses of loss and nostalgia, constructed in the process of the search" (3). It is rather notable, then, that several secondgeneration writers opt to tackle the subject of the 1980 Mariel Boatlift, easily one of the more significant events in Cuban diasporic history, and one whose generational transmissions over time have been rooted in essentializations and omissions. It signals the extent to which these writers are active participants in a critical assessment of a diasporic political and cultural history that they were not part of firsthand, but which they acknowledge to be fundamental on both personal and collective fronts. Young or not yet born during the boatlift, writers like Cecilia Rodríguez Milanés, Chantel Acevedo, and Vanessa Garcia centralize Mariel in their writing, and exercise postmemory not only to confront the thwarted Mariel memories that have been passed down in familial and public domains, but also to validate and firmly situate a "re-membered" Mariel in the Cuban-American diasporic trajectory.

As we will see, discursive commonalities among second-generation Cuban-American writers do not diminish their varied approaches and styles. In Marielitos, Balseros and Other Exiles (2009), Cecilia Rodríguez Milanés employs the short story to give voice and authorship to Mariel emigrés; she creates a specular relationship between author and narrators to combat the absolutist Mariel discourse that has gone uncontested for so many years. In her novel, A Falling Star (2014), Chantel Acevedo centers on the story of two separated marielita sisters to reaffirm Cuban America's inability to arrive at individual and collective wholeness without a deliberate examination of the past; in particular, Acevedo's postmemorial exercise scrutinizes the visual, especially family photographs. And then there is Vanessa Garcia's selection "This is Not a Neon Sign" (2019), emblematic of the second generation's interrogations of the past through a transnational imaginary. In the piece, Mariel is a defining moment for Cuban diasporic identity, with the text venturing so far as to present a transnational marielita through the lens of a transnational $\mathrm{ABC}$ narrator/author.

This Cuban-American "contemporary literature of Mariel" is all the more significant when examined in light of the Mariel literary generation of the 1980s/1990s: the "Generación del Mariel." While the group 
received some limited critical attention in the eighties and nineties, ${ }^{1}$ during this time Mariel writing was not as widely available nor well-known. With the exception of Reinaldo Arenas, whose work tended to be examined more in alignment with Latin American than with exilic contexts, it was not until the 21st century that writers like Guillermo Rosales and Carlos Victoria, among others, would receive wider recognition. These writers had been shunned in Cuba, and in exile found it difficult to be published or to reach broad readership, and also to be part of established Cuban-American circles. As Victoria observes: "Esta misma insatisfacción, que entre otras formas se filtra en nuestros textos al poner en evidencia las fallas, no solo de allá, sino también de aquí, nos ha vuelto sospechosos a los ojos de la gente que más debía tomarnos en cuenta: nuestros propios compatriotas en un país que nunca será el nuestro" (72). ${ }^{2}$ This positioning would echo the very silencing and marginalizing of the Mariel exodus that second-generation postmemorial Mariel writers attempt to counter. Their 21st-century looking back at the exodus and its aftermath carves a legitimate space for Mariel in the trajectory of Cuban-American diasporic history, and symbolically asserts the cultural relevance of Mariel writing, both past and present, within that history.

Parting from the notion that second-generation postmemory can extend our understanding of trauma's intergenerational transmissions (Blejmar and Fortuny 1), it is critical to examine contemporary Mariel writing in light of the fresh attention given in recent times to the exodus and to the "Generación del Mariel." It seems quite plausible that this greater attention served as a gateway for revisiting the past, and that second-generation Cuban-American writers are using that aperture to openly contend with what has been passed down about Mariel in order to engage more effectively with the present and futurity of Cuban diasporic identity.

"Generación del Mariel" narratives dually derive from and reflect the alienation experienced by their writers both in Cuba and in the U.S. Considered outcasts on the island, and subsequently shunned in exile by U.S. society and by established first-generation Cuban exiles threatened by Mariel's disruptions to their model-minority status and to their nostalgic memories of Cuba, Mariel exiles and Mariel writers struggle to adhere to any particular community. Left with the written word as their most liberating avenue for selfexpression, many "Generación del Mariel" writers craft works that become mirrors of the self-affirmation achievable only via the creative act. These narrations of self, or autobiographical fictional acts, as I have discussed elsewhere, become reflections of the very estranging conditions that prompted writing as an outlet in the first place. ${ }^{3}$ In the process, many of these writers create a specular relationship with their narrating characters, and denounce not only the conditions in Cuba that prompted their exile, but also the conditions in the U.S. that impeded their full integration into American society and into Cuban diasporic circles. "Generación del Mariel" literature thus holds an important place in the catalogue of Cuban-American literature. I contend that the second-generation's contemporary interventions in Mariel writing belong to that same catalogue, thus revealing a trajectory of Mariel literature that spans from the 1980s until the present day. What "Generación del Mariel" writers denounced in their writing is actively recuperated, re-voiced, and re-membered via writers like Cecilia Rodríguez Milanés or Vanessa Garcia, who revisit and determinedly position Mariel within a now more complete Cuban-American diasporic landscape.

Beyond publishing houses like Ediciones Universal or Editorial Betania, Mariel literature was not widely available early on, making dissemination even among scholars difficult. Guillermo Rosales's ${ }^{4}$ autofictional Boarding Home (1987) is an illustrative example of the unconventional journey of "Generación del Mariel" literature. The novel is narrated by William Figueras, whose characteristics establish him as a specular double of Rosales; namely, they have both been shunned by their established Cuban-exile families because of their mental illness, and forced to live in substandard Miami boarding homes. Moreover, both Figueras and Rosales seek refuge from their marginalized existence via the creative act: Figueras through his vivid dreams and the poetry he consumes, and Rosales through the text itself. Operating on multiple registers, the novel is a damning indictment of life in the U.S. for Mariel exiles who are never given a real chance at integration and

\footnotetext{
${ }^{1}$ Although not a comprehensive examination, an early assessment of the "Generación del Mariel" is Lillian D. Bertot's The Literary Imagination of the Mariel Generation, The Endowment for Cuban American Studies of the Cuban American National Foundation, 1995. Revista Encuentro dedicated a whole number (8/9 Spring Summer 1998) to the "Generación del Mariel." The Mariel group was also included in Carlos Espinosa Domínguez's comprehensive El peregrino en comarca ajena: panorama crítico de la literatura cubana del exilio, Society of Spanish and Spanish-American Studies, 2001.

2 My translation: "And this same dissatisfaction, which amongst other ways filters into our texts by highlighting the flaws, not only over there but also over here, has made us suspect in the eyes of those who should most take us into account: our fellow countrymen in a nation never to be ours."

${ }^{3}$ See Raúl Rosales Herrera, Fictional First-Person Discourses in Cuban Diaspora Novels, Mellen, 2011.

${ }^{4}$ Rosales arrived in the U.S. a few months prior to the Mariel Boatlift. However, his life and literary trajectories, both in Cuba and in the U.S., plant him firmly within the "Generación del Mariel" group.
} 
are instead ostracized to the invisibility of the margins. This dynamic is mirrored by the work's own trajectory. Written in the confines of the boarding home where Rosales was residing after his family's rejection, the novel is rescued by Rosales's friend and fellow writer, Carlos Victoria. Published in 1987, the novel received the top prize in the Letras de Oro literary contest, presided that year by Octavio Paz. However, what should have been a defining moment for Rosales and Mariel literature was not; despite being called a masterpiece, the novel received scant critical attention and Boarding Home's already-limited publication run ceased when the Letras de Oro contest was called off. And so, the text remained largely in the shadows for over two decades.

Even Reinaldo Arenas's case stands out. His work had already received recognition, yet Arenas's literary production after leaving Cuba was not viewed in relation to its adherence to the larger body of Mariel literature. For example, El portero (1989) has largely been examined in light of its surrealist and performative content, and as a metaphorical rendering of exile. And while these approaches are valid, there is also no doubt that, as a Mariel text, the novel shares parallels with other Mariel works. El portero centers on a Mariel exile's alienation in the U.S., as well as on the ostracism he experiences in his role as the doorman of a Manhattan apartment building where the only connections he can establish are with the tenants' pets. Clearly, as a simultaneous commentary on, and reflection of, Mariel life through the acting-out of symbolic action, Arenas's novel mirrors Rosales's Boarding Home, as well as other "Generación del Mariel" texts, like Miguel Correa's Al norte del infierno (1983), Leandro "Eddy" Campa's poetry, and the short fiction of Carlos Victoria and Esteban Luis Cárdenas. In all of these works, attempts at integration and belonging are futile, and the relationship between authorial self-representation and the texts' fictional selves highlights that the only achievable space for representation and affirmation lies in the text itself. ${ }^{5}$

In the new millennium, the Mariel exodus receives greater attention. Mariel generation literature becomes more broadly accessible to readership and academic scholarship as well. While there are overlaps or tangential connections between both currents, it would appear that they function rather independently. On the one hand, the exodus itself, particularly its historical and political markers, was exposed publicly in ways that validated the event's significance within the collective domain of Cuban America. On the other hand, the "Generación del Mariel" literature that was examined more broadly during the same time depicted the contours of Mariel identity and the social dynamics that voided the "marielitos" from the centers of CubanAmerican diasporic culture. The former current certified Mariel as a pivotal Cuban diaspora event, while the latter autofictional current exposed what happened to "marielitos" in the U.S. after the boatlift as an equally critical component of Cuban diasporic history.

Over the last two decades, several projects have revisited Mariel and showcased the exodus as a critical chapter in the Cuban-American story. With a focus on the exodus's causes, the ordeals at the Peruvian embassy, and the ensuing chaotic boatlift, they help retell the Mariel story from the unique perspective of both Mariel exiles and individuals in Cuba. Among these projects are Lisandro Pérez-Rey's documentary Más Allá del Mar (2009), James Carleton's documentary Voices from Mariel (2011) and the oral history collection of the same name (2018) by José Manuel García. Other publications include Susana Peña's Oye Loca: From the Mariel Boatlift to Gay Cuban Miami (2013), Florida and the Mariel Boatlift: The First Twenty Days (2014) by Kathleen Dupes Hawk, et al, and Victor Andrés Triay's The Mariel Boatlift: A Cuban American Journey (2019). Yet, the most prominent intervention has been perhaps Mirta Ojito's 2005 journalistic memoir, Finding Mañana: A Memoir of a Cuban Exodus.

Praised for sharply examining the exodus's history, Finding Mañana (and its Spanish translation) received critical acclaim and facilitated a more contextualized presentation of Mariel's history into Cuban-American diasporic discourse. Mariel was discussed again in more open and nuanced ways, something undoubtedly aided by Ojito's journalistic approach as a Pulitzer Prize-winning reporter. In the memoir, Ojito oscillates between her personal experience leaving Cuba as a teenager via Mariel and a meticulous account of the boatlift and its key players. Yet, while expounding on the historical relevance of interconnected elements that convey a more complete account of the boatlift, Ojito's memoir does not venture very far into the story of Mariel post-exodus, nor into the experiences of Mariel exiles in the U.S. Thus, while Ojito's text represents an invaluable contribution to Cuban-American and Mariel studies, and stands out for its poignant blending of reporting and family history, it underscores a part of the Mariel story that has persistently remained in the margins: Mariel exiles' broader alienation, as exposed by the self-representational fictions of "Generación del Mariel" writers. Ann Louise Bardach, in reviewing Finding Mañana, extols Ojito's efforts to "bestow some

\footnotetext{
${ }^{5}$ It is important to note that these Mariel writers found a limited avenue for collective self-expression through the founding of literary magazines like Término, Linden Lane, and Mariel. Of these, Mariel became the most important space for "Generación del Mariel" writing.
} 
belated dignity on this ragged stepchild of exile history," while also noting that Ojito has "dodged the larger issue of exile intolerance and laid blame only at the feet of a handful of 'right-wing fanatics'" (Bardach). Although not Ojito's central focus (only a few pages of the memoir are dedicated to the exodus's aftermath in the U.S.), exposing the difficulties experienced by Mariel exiles in the U.S. and challenging what enabled those hardships and what sustained their broad silencing, remained a significant gap in Mariel's full reassessment. I believe that this gap comes to be filled by the creative acts of fictional texts-in other words, through the reexamination of "Generación del Mariel" writing and by the fictional inquiry into Mariel by second-generation Cuban-American writers through reparative postmemory exercises.

Interest in Mariel over the last two decades has coincided with greater accessibility to and recognition of "Generación del Mariel" literature. The 1998 number of Encuentro de la cultura cubana dedicated to Mariel writing augured what was to come. International interest in Reinaldo Arenas boomed after the release of the 2000 Julian Schnabel film based on Arenas's autobiography, Before Night Falls (1990). This prompted greater accessibility to Arenas's U.S. work, including European releases of El portero, and multiple translations of his texts, including the English-language collection Mona and Other Tales (2001). Despite having been accessible mainly via limited library availability, Guillermo Rosales's Boarding Home was recuperated in a major way. After a successful French translation thanks to Carlos Victoria's efforts, the novel was republished and marketed in 2003 by Spain's Ediciones Siruela under the title La casa de los náufragos. It included an epilogue essay by Ivette Leyva Martínez that helped reintroduce Rosales to readers and contextualize his work. This led to the novel's subsequent translation into several languages, including the 2009 English translation The Halfway House. Another example is Miguel Correa's Al norte del infierno. A revised text was published by Editorial Artimaña in 2007, followed by Green Integer's 2008 English translation. A more recent edition with Correa's updated prologue was released in 2018 by Editorial Hypermedia for its Colección Mariel. Carlos Victoria followed suit. The French translations of some of his texts at the turn of the century led to greater international recognition. In 2001, La travesía secreta received the Best Foreign Book Award in France, and in 2004 Spain's Aduana Vieja released an anthology of Victoria's short fiction titled Cuentos: 1992-2004. The English translation of his acclaimed Puente en la oscuridad was released in 2005. More recently, La travesía secreta was also released under Editorial Hypermedia's Colección Mariel, a series that also includes, among other works, Roberto Valero's Este viento de cuaresma and Leandro "Eddy" Campa's Curso para estafar y otras historias. Also noteworthy is the 2004 anthology of "Generación del Mariel" short fiction, Cuentos desde Miami, released by Barcelona's Poliedro and edited by Mariel writer Juan Abreu.

"Generación del Mariel" writing has also received greater critical attention in recent years. Several forums have brought academics and artists together to discuss Mariel and its writers. Panels dedicated to Mariel writing have become more commonplace at conferences where Cuban and Cuban-American literature and culture are represented. And, there has been a greater circulation and publication of research dedicated to Mariel writing, including scholarly journal monographs, as well as dissertations and books. ${ }^{6}$ Much of this scholarship has examined "Generación del Mariel" writers' turn to the written word, and often to the recourses of self-representational fiction, as an avenue for expressing the complexities of Mariel exilic identity. In this way, the critical lenses applied to much of this writing have noted the degree to which these texts denounce the stigmas, and contest the invisibility of Mariel and of "marielitos," in relation to CubanAmerican diasporic cultural discourse. It is this type of closed discourse, as enabled by uncontested generational transmissions about Mariel, that contemporary second-generation writing about Mariel seeks so adamantly to break open, challenge, and alter.

Second-generation Cuban-American writers embrace the greater attention and visibility granted to the exodus and to "Generación del Mariel" writing, as they recognize the extent to which a flawed and incomplete discourse about Mariel has been transmitted to younger generations. As a group that turns to family stories and myths to better understand and negotiate with present-day diasporic identity, second-generation CubanAmerican writers come to grasp that the story of Mariel, particularly the story of Mariel exiles in the U.S., is loaded with omissions, gaps, and an overriding absolutist discourse that warrants challenging. Given these writers' desire to "extract lessons from time-honored Cuban/Cuban American enclaves of memory comprised of direct and indirect experiences of things Cuban, including narratives and practices emerging from both the

\footnotetext{
${ }^{6}$ These include: Rosales Herrera, Raúl. Fictional First-Person Discourses in Cuban Diaspora Novels, Mellen, 2011; Simal, Mónica. Tres escritores de la 'Generación del Mariel' y el canon literario cubano: Reinaldo Arenas, Carlos Victoria y Guillermo Rosales, 2012. Boston U, PhD dissertation; Mirabal, Elizabeth, and Carlos Velazco. Hablar de Guillermo Rosales, Silueta, 2013; and Matute Castro, Arturo. Idas de escritura: exilio y diáspora literaria cubana: 1980-2010, 2015. U. of Pittsburgh, PhD dissertation.
} 
private and public arenas" (López xviii), I believe that these writers' propensity to engage critically with the past prompts them to unambiguously defy any markers deemed unreliable or incomplete, like in Mariel's case.

Tahneer Oksman's observations regarding postmemory in relation to the Holocaust are applicable to Cuban America; she argues that younger generations become fixated on a history they may not have lived, but that this same fixation prompts interrogations "about the impact that the previous generations' trauma has had on their own lives" (134). Mariel was traumatic on various levels for the boatlift's émigrés as well as for the established first-generation Cuban-exile community that saw itself impacted by the exodus. One might argue that the problematic discourses around Mariel could be read as the first generation's response to trauma; however, it could also be said that they were contributors to the subsequent trauma of second-generation Cuban-Americans, those who years later would question what has been passed down about Mariel, and thus carry the burden of setting the record straight. Second-generation writers undertake their critical engagement with the past, and consequently with their own diasporic identity, via deliberate postmemorial interventions. And like the "Generación del Mariel" before them, these younger writers resort to the imaginative processes of fictional narration as the optimal platform from which to tend to and contend with their diasporic selves and communities.

Hirsch elevates the creative act's importance when discussing postmemorial production:

Postmemory's connection to the past is thus not actually mediated by recall but by imaginative investment, projection, and creation. To grow up with such overwhelming inherited memories, to be dominated by narratives that preceded one's birth or one's consciousness, is to risk having one's own stories and experiences displaced, even evacuated, by those of a previous generation. It is to be shaped, however indirectly, by traumatic events that still defy narrative reconstruction and exceed comprehension. These events happened in the past, but their efforts continue into the present. This is, I believe, the experience of postmemory and the process of its generation. (Generation 107)

Applying Hirsch's reflections to second-generation Cuban-American Mariel writing exposes why fiction becomes a preferred locus to enact postmemory's "imaginative investment, projection, and creation," as it enables the symbolic expression that comes to represent what can never be fully reconstructed or comprehended. The written page thus becomes the place where at least some concerted present-day negotiation with the past can occur. This is all the more important when considering the extent to which the second generation's inherited memories of Mariel are not only often completely indirect, but also simultaneously mediated, fragmented, and blemished.

Much second-generation Mariel writing is synonymous with the creation of fictional works where inherited transmissions related to the exodus and its aftermath are remembered, challenged, and revised so as to be able to reinsert Mariel and "marielitos" more faithfully into the Cuban-American trajectory. Contemporary Mariel writing coincides with what Karen S. Christian regards as a wider tendency in second-generation Cuban-American literature. She reminds us that "many recent Cuban American novels allude to family secrets, absent memory, or topics that are taboo in family conversations. Intrigued by these missing pieces, the second-generation narrators/protagonists seek to discover, uncover, and/or recover a past that may have implications for their present and future" (94). This repeated tendency, which is also overtly evident in contemporary Mariel writing, suggests the importance of scrutinizing patterns of repetition when evaluating these texts. And, it is the case that the repeated memories about Mariel inherited by the second generation are mirrored inversely by the revision of those memories in their fictional texts. This notion aligns with Hirsch's commentary about postmemory's productive potential:

The postmemorial generation-in displacing and recontextualizing these well-known images in their artistic work-has been able to make repetition not an instrument of fixity or paralysis or simple retraumatization (as it often is for survivors of trauma), but a mostly helpful vehicle of working through a traumatic past. (Surviving 9)

Given the similar discursive approaches by writers like Cecilia Rodríguez Milanés, Chantel Acevedo, and Vanessa Garcia, Hirsch's assessment proves useful for validating why second-generation Mariel writing merits a closer holistic evaluation.

Aligned with Hirsch's theorization, second-generation Mariel fiction employs postmemory "to replace and to repair" (Past Lives 420). This is postmemory's most generative feature according to Sonali Thakkar, who posits it as "namely, the identification and description of a practice of reparative remembering that speaks to ongoing debates in literary and cultural theory about the politics of futurity" (137). Within this framework, 
contemporary Mariel writers engage in a diasporic postmemory exercise that converts intergenerational traumatic transfer into inherited memories needing repair. In fact, in exploring the relationship between neuroscientific theories and postmemory, Christian has suggested parallels between "transgenerational epigenetic inheritance" and diaspora literature (91). In her assessment of second-generation Cuban-American writing, Christian asserts that fiction can convey "a parallel between the body's genetic memory of trauma suffered in previous generations, and postmemory as the 'genetic memory' of a nation shattered by exile" (90). I believe that this dynamic intensifies in second-generation Mariel writing given what Mariel has represented for Cuban America, and given how the layers of that uncontested representation have been perpetuated. In this vein, second-generation Mariel fiction is characterized by a poetics of self-representation that is marked by the judicious assessment of diasporic identity in its past-to-present continuum, as well as by the simultaneous exploration of that identity's reconfigurations, on merging individual and collective fronts, as mediated by postmemory.

Mariel's metanarrative is plagued by essentializations about Mariel exiles, whom American society largely rejected once it was known that the Cuban regime had capitalized on the exodus to eliminate undesirables like prisoners and the mentally ill. Despite constituting a small minority of Mariel émigrés, this population of "undesirables" would become the marker under which all Mariel refugees would be viewed, including by established first-generation Cuban exiles. In addition, Mariel put before these exiles a Cuba that was also black, pagan, and homosexual-a reality many did not want to accept or remember (de la Nuez 107). What is more: "between the Mariel Cubans and those who had emigrated in the early days of the revolution lay twenty years of social and ideological differences ... The new immigrants, they feared, would never fit into their community; they were too different; they spoke and dressed differently" (García 72). This rejection was channeled into an exilic cultural and sociopolitical discourse of otherness, rooted in stereotypes and prejudice, that would be echoed repeatedly in both public and familial arenas. Thus, what would be transmitted about Mariel and Mariel exiles to younger generations, and which second-generation Mariel writing challenges through postmemory, can be interpreted as the still-tainted product of the first wave's own generational response to Mariel.

Cecilia Rodríguez Milanés's short-fiction collection, Marielitos, Balseros and Other Exiles, stands out among contemporary second-generation Mariel writing for overtly challenging the transmitted Mariel metanarrative. As a second-generation writer who lived in 1980s' Miami as a young woman, but who did not experience the Mariel exodus directly, Rodríguez Milanés negotiates, through postmemory, with "what has been passed down or what is remembered, unreliable and uninterrogated as that may be, in order to creatively construct and examine its fragmented, partial, juxtaposed, and polyphonic elements" (Rosales Herrera, Remembering 57). To do so, she sets many of the collection's stories dedicated to Mariel (there are eight in total) in the 1980s, thus employing what Richard Terdiman has labeled "representation as re-memoration" (70). ${ }^{7}$ Moreover, the characters who inhabit these stories, mainly Mariel exiles, carry out their own act of remembering, recalling particular past episodes of Cuba and/or the exodus itself that shape their current reality. The result is a specular arrangement wherein the stories' active depiction of Mariel in the present moment of narration (the 1980s), and through the characters' remembrances, is echoed by the extra-textual: namely, as the mirrors of the author's own contemporary postmemorial reparative interventions. Both author and her textual selves grapple with the past's impact on the present through the act of remembering, with Rodríguez Milanés employing postmemory to interrupt the anti-Mariel discourse that has been transmitted to her generation over decades. That she carries out this interruption by conferring active counter-discursive voices to "marielito" characters and narrators further accentuates Rodríguez Milanés's postmemorial strategy.

"La Pareja" is set in 1985 and revolves around a young homosexual couple, Salvador and Gabi, who met in Miami after arriving via Mariel. After living "unclaimed" in Miami's Tent City, the men were sent to Texas before finally settling in Miami, where they have lived in a very modest apartment for the last three years. The story offers a glimpse into their domestic lives while also portraying their struggles as "marielitos." The men work low-end retail jobs and fight to make ends meet; their economic hardship is compounded by what they need to spend on calling family in Cuba and sending money to them regularly. Narrated in vignettes, the story illustrates how much these men fail to correspond to the generationally-transmitted Mariel stereotype. They are not criminals nor mentally unstable, and their hardworking, ordinary lives align with the exilic lives of the very first-wave exiles who see them as "different" and "threatening" to established Cuban America. Moreover, Rodríguez Milanés showcases two gay characters in a loving relationship, underscoring her response to homophobic elements within the anti-Mariel paradigm. Rodríguez Milanés's

\footnotetext{
${ }^{7}$ Terdiman also points out that this construction of representation establishes memory "as the most consistent agent of the transformation by which the referential world is made into a universe of signs" (70).
} 
counter-discursive challenge, as reflected through her creative act and the Mariel voices made audible through it, highlights postmemory's revolutionary potential.

Gabi is humiliated at work when his boss, Oscar, interferes in one of his sales. Assumed to be a first-wave exile, Oscar expresses complete disregard for Gabi, not only embarrassing him, but also blocking what would have been Gabi's much-needed commission. Gabi's silence during the incident is countered by his tearful recounting of it to Salvador: "You know what he said to them, right in front of me? Laughing, he said, 'Let me take care of you, sirs. This mariquita doesn't know anything about quality watches.' Can you believe it? Can you believe it? I swear, Salvador, I was so angry I could have spit in his face" (51). Gabi's recollection operates on multiple levels. Foremost, it highlights the first generation's dehumanizing discourse, as Oscar reduces his fellow exile to nothing more than a "mariquita," even though the story, as the reflection of Rodríguez Milanés's postmemorial intervention, dismantles this discourse by showcasing the fullness of Gabi's humanity. Additionally, Gabi says, "I just stood there and stared at him. As if I were invisible!" (50), but the text at hand and its representational characters make "marielitos" visible and audible against their invisibility and silencing in Cuban America. Essentially, the incident underscores the first generation's complicity in generating the very conditions that create hardship for Mariel exiles and that feed into subsequently-perpetuated stereotypes.

The story echoes this vicious cycle several times. Gabi's next retail job is no better than the previous one: "The Guzmáns wouldn't give him more than twenty hours a week and these only at minimum wage ... By the end of the first month, Gabi was thoroughly disgusted with the store and its employers" (53-54). And the couple's economic hardships intensify: "The phone bill is going to make some problems for us, Gabi contemplated ... Their little cache of savings was all but gone" (55). In the end, anguish reigns, as symbolized when Rodríguez Milanés juxtaposes Gabi's present-day struggles with his memories of the struggles in Cuba that led to his departure via Mariel. Gabi tries desperately to survive in both places, but forces beyond him make it impossible. Implicit in this interplay is the paradoxical acknowledgement that if the Cuban regime made life unbearable for Mariel exiles in Cuba, then established exiles are doing the same in the U.S.

The story's final part eerily echoes its beginning, but this time it is Salvador who arrives home from work in despair. He largely withdraws from Gabi, refuses to eat, and remains silent, except to proclaim: "mierda y más mierda" (59). Readers are left to draw their own conclusions about what has transpired, although in its vagueness Rodríguez Milanés is signaling that the particulars are irrelevant; life will continue to be hard, perhaps even harder, for Mariel exiles like Salvador and Gabi.

"The Fresh Boys" is another story representative of Rodríguez Milanés's approach. Set in 1988, it centers on three high school students-Dougie, Papo, and Ray-all of whom are Mariel refugees. Beyond their friendship and migratory connection, the three teenagers defy any univocal assessment regarding Mariel. They are not just "the fresh boys" or the "gang" of "marielitos"; instead, Rodríguez Milanés conveys their individualized humanity when she presents in omniscient narration what is going on in each of their lives, and juxtaposes this with each boy's first-person response to a homework assignment that calls for the writing of a short autobiographical essay. This first-person narration is further split between each of the teenagers' interior monologues and the actual words of their autobiographies. The story's testimonial bent highlights once again the author's focus on giving voice to Mariel exiles and, in this case, granting those voices written control over the very text that contains them. Rodríguez Milanés's reparative postmemory exercise thus entails allowing Mariel exiles to speak and write for themselves.

Dougie's autobiography is lighthearted, oscillating between fragmented memories of Cuba and details of a typical teenage life, including information about his car and the girls he dates:

His mind wandered a bit before taking up the pen again. I can't tell you or I don't know if I can tell you what I feel about Cuba. Many times I don't know the right words. In Spanish or English ... I'm the only one in school who has a chrome engine ... I like to go out and cruise on the weekends. I go with my boys down to the Grove or sometimes to South Miami. (88-90)

In Dougie, Rodríguez Milanés normalizes the Mariel exile, placing him on the same plane as any other young teen or immigrant, and thus directly calling into question the othering to which "marielitos" have been unfairly subjected. This point is further illustrated when Dougie presents his parents as antithetical to any Mariel stereotype; they are employed professionals fulfilling the so-called American Dream: "My mom works at a bank on Brickell Avenue and my dad works downtown at the college ... My dad's really smart, he does interior designs and fabrics and ... can draw really nice" (89).

Papo is also an average teenager in many ways, yet his account does reveal the trauma of Mariel. His autobiography explains his turmoil at not wanting to leave Cuba, and then at having to confront actos de 
repudio once it was known that his family would be leaving via Mariel. The memory is triggering for Papo, who externalizes his psychological pain by nervously tearing away at his cuticles as he writes:

I didn't want to leave at first but my mother's family here in Miami gave our names to some people who had a boat ... My mother was thrown out of her job. Papo bit his right thumb some more ... He pressed down hard on the paper. The people she worked with hit her and kicked her out. There was blood on his finger where he had pulled some dead skin off so he stuck it in his mouth and continued. $A$ group of students ran after my dad with rocks and sticks ... I was spit on which made me very angry but they wouldn't not listen to me. I kept telling them, I want to stay, I don't want to go. But even my friends called me gusano. (92)

Papo's anguished memory of his repudiation in Cuba is matched by the painful memory of his rejection in exile; he explains that his mother's family in the U.S. pushed him away soon after his parents' tragic deaths:

He sucked some more blood from his finger and yanked another bit of skin from the other side of his fingernail ... My mother's cousins didn't want anything to do with me because they said I was trouble. Ha, if they only knew that their angel Susanita was doing crack! ... I went to live with them for a few months but it was impossible ... Manny was my best friend and my mom worked with his mom so they let me stay. (93-94)

Ultimately, Papo's autobiography showcases the double exile of Mariel émigrés, who are rejected in Cuba and then again in the U.S. by the very Cuban family and community that should welcome them. That we learn Papo is a good guy mostly interested in baseball, and who is not actually "causing any trouble," further highlights the unfair ostracism confronted by Mariel exiles, and echoes the same marginalization denounced by "Generación del Mariel" writers like Guillermo Rosales decades before. Rodríguez Milanés signals that any potential fulfillment of the Mariel stereotype will be the direct result of Papo's exclusion by established Cuban America. In doing so, she exposes the rather ironic, analogous tendencies between first-generation exiles and the Cuban regime. Part of Rodríguez Milanés's reparative use of postmemory involves the desire to prompt a deliberate reflection of this paradox.

Lastly, Ray's autobiography is quite different. Prior to his writing of the essay, it is revealed that Ray's poor grades will likely land him in summer school. He is also having sex with his girlfriend, but is frustrated that the girl he really cares for will not sleep with him. Moreover, Ray is exasperated and guilt-ridden because he is unable to fulfill the expectations of his hard-working mother, who toils away for long hours in a factory to provide for him. Bitter at the conditions of his life and his mother's, Ray represses his anger when it appears to overwhelm him: "Hot salty tears burned him but before they could fall, he wiped them away and jammed his chin into his chest to steady the shaking ... I gotta get my shit together he said to himself" (98). Yet, the written words of his autobiography provide Ray with an outlet for his anger, and-in metafictional parallel to the very story that contains his text-they offer a positioning that liberates him from the confines of the same Mariel metanarrative he would be expected to inhabit:

What the hell do you wanna know about me anyway? ... It's none of your fucking business. He was sweating and reading as he wrote. What for? So you can call my mother and bother her with bullshit? She works nights and sleeps days, allright ... You people make me sick. Think you know everything. You don't know shit about me, allright? (99)

In giving voice to Ray's angst, Rodríguez Milanés grants the Mariel exile room to offer his own perspective and thus challenge the dominant discourse that would be created and perpetuated by established Cuban Americaone in which Mariel exiles would have no say. Thus, as a reflection of Rodríguez Milanés's own present-day exercise as a second-generation Cuban-American writer, Ray's discourse in the 1980s-set story provides Mariel a literal space for expression. And, as April Shemak observes, this space grants Mariel exiles a long-overdue agency: "Because of his marginalized position, Ray is not a New Immigrant-native informant, although his refusal is an attempt to exert agency, to wrest the power over discourse away from the institutionalized host" (239).

Rodríguez Milanés's other Mariel-centered stories also hone in on the humanity of Mariel exiles, and how many are ostracized despite having the same goals and aspirations as their first-generation exile counterparts. For instance, the familial rejection by first-wave exiles in "The Fresh Boys" is also present in "Abuela Marielita," where an established Cuban-American family subscribes to the Mariel stigma and is ashamed that 
their grandmother is a Mariel exile; they desperately hide the fact from others and end up marginalizing the grandmother, who ultimately connects more with the equally-alienated marielita tenant who lives out back than with her own blood relatives. Reminiscent of "La Pareja," in "La Buena Vida" the hardworking Juan is berated both at his job and by his cousin's family for simply being a Mariel exile. Wanting nothing more than to work hard and to eventually achieve the kind of life he sees first-wave exiles enjoying, Juan is nevertheless not given the chance; he is expelled from both his job and his cousin's home, and forced into homelessness. Once again, we see the first generation occupying a paradoxical parallel with the Cuban system it opposes, but that similarly afforded Juan and those like him no shot at a better life.

Reparative postmemory also engages in a deliberate deconstruction of the Mariel stigma by actively debunking various Mariel stereotypes. As seen in how Rodríguez Milanés presents the homosexual couple in "La Pareja" and the "gang" in "The Fresh Boys," her contrapuntal strategy is also evident in several other stories. At the end of "La Buena Vida," the homeless Juan, who we know was pushed to destitution through no fault of his own, ends up getting murdered by a fellow Mariel exile. However, this "murderer," who would seem to be fulfilling the criminal stereotype attached to "marielitos," is depicted as severely mentally ill in the story "El Loco." His "craziness," another component of the Mariel stigma, is contextualized in the story down to its most human dimensions when we learn more about the protagonist through his interior monologues and discover the horrible abuse to which he has been subjected his whole life.

Perhaps the most poignant counterpoint within Rodríguez Milanés's collection is also the most explicit rebuttal to dominant Mariel discourse; in the 1984-set "A Matter of Opinion," the character of Carmen literally confronts the vicious anti-Mariel discourse that is emanating publicly from talk radio. Carmen accomplishes what Rodríguez Milanés achieves through the text itself many decades later: "In a doubling act that has Carmen as the exception and Rodríguez Milanés as the interrogator of an unchallenged past, the text suddenly becomes the battleground for second-generation cultural negotiation" (Rosales Herrera, Remembering 61). In the story, Carmen (and Rodríguez Milanés) break down and debunk passed-down assertions about Mariel exiles, and once again dually force first-wave exiles to reflect on what they share with their fellow Cuban émigrés, while also recognizing their resemblance to the Cuban regime in their denigration of "marielitos." In response to the talk-show host's anti-Mariel diatribe in which he mentions Castro having unleashed criminals and lunatics on the U.S., Carmen states: "Mr. Guerra, you are too smug. Your family is free here, wealthy here ...What of those families, those persons whose entire families are still in Cuba waiting? ... I take it you trust Castro's judgments? ... you trust Castro's judgments?" (23). As the example's counter-discourse illustrates: "Rodríguez Milanés's representations go beyond historical depiction and revaluation, engaging instead, through fiction, with the varied, nuanced, and contradictory essences that have been absent from generational transmissions of the Cuban exile experience regarding Mariel" (Rosales Herrera, Remembering 66).

In the end, Rodríguez Milanés promotes postmemory's importance in the development of diasporic identity by resisting the absolutist trappings that have dominated generationally-transmitted Mariel discourse. As Jennifer Bowering Delisle notes: "the second generation's longing for the times and places of their ancestors' stories [is] a nostalgia drawn not out of direct experience, but out of the very gaps between personal memory and genealogical legacies" (138). In this way, second-generation Mariel writers transform a nostalgic longing for the past they did not experience into a rather anti-nostalgic intervention that seeks to repair generational transmissions that, while damaged, continue to be damaging. Thus, Mariel fiction serves as an exemplary battleground for postmemory's struggles, as what has been internalized by the second generation is simultaneously exercised and exorcized by and through second-generation Mariel writers and their fictions' representational and narrating selves.

The diasporic postmemory of second-generation Cuban-American writers when it comes to Mariel also ventures into direct engagement with the memory markers of the exodus. In other words, Mariel must be remembered; and part of the work of reparative re-memoration is not only to challenge anti-Mariel discourse, but also to accentuate Mariel's existence in Cuban America's personal and collective memory. Thus, a significant part of changing the discourse around Mariel involves "unsilencing" the exodus and removing it from the shadows of shame where it has rested for so long. It embraces discussing the boatlift and its aftermath openly, beyond stigmas and taboos, as a vital piece of the Cuban-American story. This "unsilencing" needs to take place in the public arena, but also within the private realm of the familial:

In diasporic fictional representations, the past is both affirmed and interrogated through a direct symbolization that privileges memory over history, but yet strives for an affiliative connection that paradoxically goes beyond the familial by employing the family narrative as a way of inserting the diasporic Cuban American subject within the wider web of collective Cuban American national and cultural history. (Rosales Herrera, Diasporic 34) 
As we have seen in Rodríguez Milanés's fiction, and even in Mirta Ojito's Finding Mañana, the family narrative is central in this endeavor. The novel A Falling Star by Chantel Acevedo also openly uses the family narrative-in this case, to highlight how images can shape and distort memory, and also ultimately impact Mariel postmemory.

The reparative postmemory of second-generation Mariel writing engages with the acting-out of symbolic action in the past in order to comment on that past from the present. A Falling Star establishes this commentary mainly through the incorporation of visual elements that speak to what remains visible but also incomplete about Mariel. Born in Miami to Cuban parents, Acevedo learned about Mariel from the stories of others, and credits Ojito's memoir for providing historical information to her about the exodus (278). Thus, Acevedo's own relationship with Mariel reflects the silence and absent stories about the exodus that her novel attempts to recuperate and repair through the memories of its adolescent protagonists, the separated sisters Daysy and Belén/Stella, with whom Acevedo establishes a duplicative relationship. Daysy and Belén/ Stella are on a mission to uncover their past regarding Mariel, and Acevedo employs the photograph as the postmemorial symbol through which the sisters (and the novel itself) will unlock Mariel discourse into their lives and into Cuban-American history.

Acevedo's novel does not center on the ostracism of Mariel exiles as prompted by generationally-transmitted anti-Mariel discourse, focusing instead on making Mariel visible and accessible to readers (and to Cuban America) through the novel's symbolization. The text's fragmented order includes chapters dedicated to preMariel Cuba and to the Mariel Boatlift. These sections, in turn, contextualize the chapters set in present-day 1990 that center on the separated sisters. This setup represents the degree to which the past is determinative for the sisters' present and future, but yet remains inaccessible. During the chaotic and perilous maritime journey after leaving Mariel harbor, baby Belén is separated from her parents, who believe that she has drowned. They keep the baby's existence a secret from older sister Daysy, who will grow up having very loose memories of the ordeal. For her part, Belén is actually rescued and arrives to the U.S. on another vessel, and is raised as Stella by another family. Ten years later, 14-year-old Daysy and 10-year-old Belén/Stella each yearn to understand their past but are met with parental silence. Echoing the larger discourse around Mariel, neither family wishes to broach the subject, preferring to conceal their trauma, but failing to recognize how their silence is also traumatizing for the sisters and their sense of self. Here, Hirsch's "fullness of postmemory" (Past Lives 422) coincides with the "fullness" of identity that the sisters pursue, which, in turn, symbolizes the larger diasporic "fullness" that the novel seeks by integrating Mariel wholly into the Cuban-American story.

The novel explores the sisters' relationship with the past through photographs, both the exodus's historical photographs as well as the personal family photographs that are connected to Mariel. In this way, Acevedo capitalizes on one of postmemory's most powerful tools. As Hirsch details:

Photography's promise to offer an access to the event itself, and its easy assumption of iconic and symbolic power, makes it a uniquely powerful medium for the transmission of events that remain unimaginable. And, of course, the photographic meaning of generation captures something of the sequencing and the loss of sharpness and focus inherent in postmemory. (Generation 107-108)

For A Falling Star's sisters, photographic images represent their only conduits to a silenced past whose memories they yearn. As static, fragmented moments of that past, photographs become the catalysts that will enable the sisters to uncover what their families have concealed about Mariel. The historical photographs will facilitate a fuller understanding of the human elements within them, and the family photographs will prompt the verbal transmission necessary to accompany the evidence of the past triggered by the visual. Regarding the latter, Hirch notes: "Family photos, and the familial aspects of postmemory, would tend to diminish distance, bridge separation, and facilitate identification and affiliation" (Generation 116). And so, when Daysy finds an old family photo that features a baby she knows nothing about, the discovery allows her to make connections with the dreams she is having about her fragmented memories. Additionally, the photograph makes the importance of generational transmission clear to Daysy; she needs the verbal narrative denied to her for the photo/past to make "full" sense in the present. This is clear when she asks her Alzheimer's-stricken grandfather about the photograph and he responds, in a moment of lucidness, with: "Your ignorance is your parents' doing. When Nieve and I were told Belén had drowned on the way to Florida, that she fell into the ocean somewhere between Mariel and Key West, ay, que sufrimiento!" (18). This verbal narrative unleashed by Daysy's grandfather leads her on a journey to understand Mariel as a vital component of her existence and her identity. The partiality offered by news reels, the static nature of the photograph, and her grandfather's incomplete narrative become symbolic markers of Mariel within the Cuban-American trajectory. 
The novel's specular setup is further exalted through the symbolization of Belén/Stella as the personification of Mariel. Daysy's quest for her sister, for herself, and for Mariel are one and the same. In this complex interplay with the past, photographs come to symbolize more than "information or confirmation," and also become the source for "an intimate material and affective connection; they become "spaces of projection and approximation and of protection" (Hirsch, Generation 116-117). Eventually, a series of interconnected events lead to the discovery that baby Belén/Mariel are very much alive, prompting a reunification of the sisters and the "fullness" of the family. And it is no coincidence that Acevedo opts for photographs to again be the catalysts for this "fullness" when Daysy and her mother Magda Elena confirm Belén's identity:

Together, they tumbled toward Magda Elena's bedroom and the closet where she kept the yellow suitcase ... 'Mira, mira. Look! My baby, look at her,' and she held up pictures of Belén ... Here she was propped up on a sofa ... And there, another photograph of Belén in Daysy's lap ... In all the photographs, the birthmark was visible. (229)

Ultimately Acevedo's novel challenges readers to scrutinize the links between experience, images, and memories-the same pieces so crucial for the diasporic postmemory of Mariel.

A Falling Star further underscores issues related to postmemory's futurity, as Acevedo calls attention to how the particular past of Mariel, equally traumatic and silenced, is an indelible part of the history and identity of younger Cuban-American generations. In this vein, Ernst van Alphen has highlighted how the "problem which causes trauma is not the nature of the event by itself, or any intrinsic limitation of representation per se, but the split between the living of an event and the availability of forms of representation through which the event can be experienced" (482). As a representative re-memoration of Mariel, and through the specularity it achieves between the textual and the extra-textual, A Falling Star stands out for highlighting how the second generation recovers, and ultimately needs Mariel, to arrive at the "fullness" of diasporic subjectivity and identity. This dynamic is epitomized by Daysy, who at the novel's end has been reunited with her past/Bélen/Mariel: "She closed her eyes against the pale pinpricks of light in the sky. The world felt steady under her, though she knew it was rocketing around the sun at unimaginable speed. No, she'd never felt this sure on her feet" (236).

Postmemory scholars, including Hirsch, have expressed a preoccupation with how second-generation inheritors of past memories and traumas are able to carry on in the realms of both the personal and the collective: "Hirsch expands the concept of postmemory to describe a broader social structure, in which the intergenerational inheritance of trauma organizes politics, demanding an engagement with the past if it is not to overwhelm the future" (Thakkar 139). As we have seen, the postmemorial Mariel works of second-generation writers like Rodríguez Milanés and Acevedo underscore this important characteristic of postmemory, given the extent to which Cuban diaspora writers (and their doubling narrative subjects) are compelled to access Mariel's past in order to make sense of the present and to give continuity to their lives. Furthermore, contemporary Mariel fiction serves as a perfect illustration of how "the structure of postmemory allows and even demands agency and creativity of the second generation, not least with respect to practices of commemoration and representation" (Thakkar 139). Postmemory's futurity, as conveyed through symbolization and representational re-memoration, is a hallmark of second-generation Mariel writing, and this futurity takes on even greater weight when considering some of this writing's transnational scope. Some secondgeneration writers access the Mariel past in their fiction, but also have their Mariel characters return to Cuba or move between Cuba and the U.S. This transnational inclination aligns with the futurity of the diasporic subject in as much as it echoes that subject's increasingly-sustaining identitary hybridity.

Worth mentioning briefly is Derek Palacio's The Mortifications (2016), which revolves around a family that flees Cuba on the Mariel Boatlift and that, after a series of complex circumstances, eventually returns six years later. Although the boatlift and its aftermath are not the novel's central foci, Palacio's deployment of Mariel as the defining marker of his transnational family saga is relevant. Once again there is a compulsion to revisit Mariel in contemporary fiction via re-memoration, and to make the event a critical one for diasporic/ transnational identity, even if, in Palacio's case, he provides no direct commentary on Mariel beyond the general impact of the past and of exile on his characters' psychological makeup. Indeed, in her review of the novel, Victoria Baena offers an assessment that aligns Palacio with fellow second-generation writers in terms of how the past shapes and informs present-day diasporic experience, but that also separates the author from Mariel writers who more intentionally explore the specific role and place of Mariel in Cuban America:

While the island is described with vivid sensory detail, the characters' relationships to Cuba have perhaps more to do with their painfully abstracted relationships to each other than with the island itself. If other contemporary novels of the American immigrant experience have worked to portray 
the cultural slights and acute misunderstandings that arise from attempting to integrate, Palacio is more interested in the way the psychological resonance of past times and places is amplified by the experience of exile-and in meticulously chronicling the physical, bodily expression of this experience. (Baena)

In terms of the transnational positioning that Baena references, Vanessa Garcia seems to be on the other side of the spectrum from Palacio. Her piece, "This is Not a Neon Sign," ${ }^{8}$ expounds directly on its characters' relationships to the island in light of their multicultural and aforementioned hybridity. Moreover, the text makes an explicit commentary about the past and the futurity of diasporic experience by examining Mariel through a transnational present. The story is narrated in first-person by Vero, a second-generation Miamiborn Cuban (like Garcia), whose visions of boats have led her to Cuba on a mission to understand the full essence of who she is as a Cuban-American. The piece is set entirely in Cuba in 2017, in the aftermath of the 2016 U.S. election, and shortly after Vero has gotten married. An installation artist, Vero has travelled to Cuba alone not to pursue her work; she spends her days instead sketching Havana and trying to understand the relevance of her visions. On the one hand, she recognizes that "everywhere I turn in Havana there's a piece of me" (97), while dually questioning her belonging: "every bit of me is from here and not from here. I'm a 'Miami Cuban'" (93). This embracing of hybridity in an autofictional work set in Cuba within a transnational imaginary is emblematic of López's assertions regarding second-generation Cuban-American writers and their less-absolutist relationship with exile politics: "There are no longer young characters who singlemindedly take sides regarding Cuba ... these writers go beyond Cold War, anti-Castro rhetoric, acquiring more of an immigrant stance in their search for a more judicious and nuanced approach to Cuban America" (xxiv). In Garcia's story, this dynamic is all the more poignant given the inclusion of Mariel.

Vero's good friend is Roberta, a lesbian architect and Mariel exile who has officially repatriated to Cuba, splitting her time between Havana and Miami. Vero is too young to remember Mariel, so it is notable that a considerable portion of Vero's first-person narration is dedicated to her postmemories of Mariel vis-a-vis Roberta and her experiences. Vero and Roberta's friendship, and their sharing of a hybrid and transnational reality that puts them in parallel positioning, exemplifies how Garcia dually revisits and reinserts Mariel in the diasporic and transnational present. Moreover, given the specular extra-textual relationship between Garcia and Vero, and the intra-textual relationship between Vero and Roberta, Garcia's postmemorial intervention also stands out for inextricably linking Mariel to diasporic futurity. Garcia accomplishes this through two channels: she breaks down the flawed, inherited transmissions about Mariel by juxtaposing them against Roberta's reality, and she validates how much the younger generations "need" Mariel as part of their own diasporic and transnational journey.

In narrating Roberta's experience as a Mariel exile, Vero provides an account of the exodus while simultaneously making a commentary on how it would be remembered decades later, thus explicitly mirroring how Garcia is employing postmemory in the text:

That year, Robertica's family, like so many others, had rushed into the Peruvian embassy in Havana, hunkering down and searching for a way out of the island. Ten thousand people flocking toward sanctuary, saying: Get me the fuck out of here! So, what did Fidel do? He said: you don't want to be here, fine. Go, and take the crazy people and the prisoners with you. Then he opened the jails and the mental hospitals and sent all of Cuba's "human waste," as he called it, over to the 305. Anybody who could, got on a boat at Mariel harbor and left. Along with the criminals, there were brilliant writers and artists, gay men who had been persecuted for years, and families like Robertica's. What people remembered though were the crazies and the criminals, which meant that arriving in Miami as a thirteen-year-old marielita wasn't fun. (98)

Vero's narration sets the record straight about Mariel by challenging the generational transmissions that have perpetuated the anti-Mariel discourse that has locked Mariel exiles within the parameters of stereotype, invisibility, and marginalization. Echoing some of Rodríguez Milanés's stories, Garcia humanizes the exodus and its aftermath, but does so even more explicitly from the transnational present-day vantage point of the text and its narrator. Garcia's/Vero's homage to the "brilliant writers and artists" of Mariel would seem to be a direct reference to the "Generación del Mariel" writers and artists that have received much attention

\footnotetext{
8 "This is Not a Neon Sign" is included in the anthology Let's Hear Their Voices. On her website, Garcia states that the selection is an excerpt from a novel in progress of the same name.
} 
recently-an attention obviously reflected by Garcia's own text. Roberta herself becomes the embodiment of these artists in the present day, as she is presented as an incredibly successful gay woman and well-known architect. Her reality challenges all of the stereotypes associated with Mariel exiles, and her life has been guided by resisting these at all costs, as illustrated by Vero's memory of the reaction of Roberta's family to Roberta stealing a pair of shoes when she was a teenager: "'You're playing right into what they think of us,' her father screamed. 'You're saying they're right! That we're all a piece of shit, you stupid, stupid, stupid girl!'” (98). Thus, Garcia's story affirms that resisting the Mariel stigma becomes both the task of the Mariel exile, as well as the task of the second-generation writer intent on engaging with Mariel today.

Despite the differences in their generations and in their life experiences, Vero and Roberta are tightly bonded through their mutual experiences as women artists who are navigating the dual spaces of their Cuban-American transnational identities. As she yearns to fully understand herself and her complex identitary relationship with Cuba, Vero sees in Roberta a role model for her quest:

Is this what Roberta feels all the time, now that she's officially repatriated? What a strange word. What a strange thing: claiming your country again, allowing it to claim you-after all these years. I've thought about doing it, what she did. They let the children of Cubans do it, so even me, ABC, American Born cubanita, 'Cubanita de Miami,' even I could repatriate. (95)

This dynamic not only suggests the firm place of Mariel and of "marielitos" in the lives of younger Cuban America, but also indicates how much that younger Cuban America needs Mariel for its diasporic journey. Vero's transnational experience as an $\mathrm{ABC}$ and how she processes her diasporic identity in light of her relationship with Cuba garners greater significance when viewed alongside Roberta's reconnection with Cuba as a Mariel exile despite the trauma of the exodus and its aftermath. Bearing in mind how second-generation diasporic experience (inclusive of cultural production) deals not only with the past, but is also about visualizing new and continuing collectivities, Roberta's representation in "This is Not a Neon Sign" both validates Mariel's place in Cuban diaspora history, and also affirms Mariel's place in that diaspora's transnational futurity. As Vero declares when she contemplates Roberta's experience alongside her own: "Because she wants to be part of the rebuilding of her birth city, she says, whenever that becomes possible. Right now, Cuba isn't letting her do jack in terms of designing, but there's always the future" (99).

In discussing Eva Hoffman's ideas regarding the postmemories of the Holocaust generations, van Alphen explains that:

[These] became narratable not because they processed their memories, connected pieces of memory into a coherent epic. The coherence rather came from outside, through literature and film, through memoirs and testimonies of others, which circulated more and more in public culture ... They provide the narrative framework in which memory fragments can be integrated. (485)

As we have seen, second-generation Mariel writing follows a similar trajectory of postmemory, thus reinforcing how much Mariel widens the scope to promote ongoing inquiries and discussions regarding the intersecting dimensions of memory, experience, images, history, and identity in the Cuban diaspora. In the end, the dual legacy and continuity of Mariel in private and public discourses, as facilitated by the reparative interventions of younger generations and their fictions, have the potential to facilitate more open (and open-minded) conversations, not only about the evolution of diasporic literature and discourse in Cuban America, but also about memory's critical role in shaping both. Ultimately, the complex interplays of memory and postmemory regarding Mariel that are evident in the ABC writers of Cuban America, and in the characters that populate their self-reflective texts, unearth our own potential for realizing and acknowledging how we too can be transformative agents of the past and of memory, and not just their static and passive hosts. Our futurity and the "fullness" of our identity and our history depend on it.

\section{Competing Interests}

The author have no competing interests to declare.

\section{References}

Acevedo, Chantel. A Falling Star. Carolina Wren Press, 2014.

Baena, Victoria. Review of The Mortifications by Derek Palacio. Bookforum, 17 Oct. 2016, www.bookforum. com/culture/the-mortifications-by-derek-palacio-16721. Accessed 10 Mar. 2021. 
Bardach, Ann Louise. "Marielitos and the Changing of Miami." Review of Finding Mañana: A Memoir of a Cuban Exodus, by Mirta Ojito. Los Angeles Times, 24 Apr. 2005, www.latimes.com/archives/la-xpm-2005apr-24-bk- bardach24-story.html. Accessed 18 Mar. 2021.

Blejmar, Jordana, and Natalia Fortuny. "Introduction." Journal of Romance Studies, vol. 13, no. 3, Winter 2013, pp. 1-5. DOI: https://doi.org/10.3828/jrs.13.3.1

Bowering Delisle, Jennifer. "Genealogical Nostalgia': Second-Generation Memory and Return in Caterina Edwards' Finding Rosa." Memory Studies, vol. 5, no. 2, 2011, pp. 131-144. DOI: https://doi. org/10.1177/1750698011415249

Christian, Karen S. "Postmemory, 'CubAngst,' and the Genetics of Trauma in Cuban American Fiction." Reading Cuba: Discurso Literario y Geografía Transcultural, edited by Alberto Sosa Cabanas. Aduana Vieja, 2018, pp. 89-103. DOI: https://doi.org/10.1353/yale.2001.0008

Encuentro de la Cultura Cubana, vol. 8/9, Spring/Summer 1998,

Espinosa Domínguez, Carlos. El peregrino en comarca ajena: panorama crítico de la literatura cubana del exilio. Society of Spanish and Spanish-American Studies, 2001.

García, María Cristina. Havana USA: Cuban Exiles and Cuban Americans in South Florida, 1959-1994. University of California Press, 1996.

Garcia, Vanessa. "This is Not a Neon Sign." Let's Hear Their Voices: Cuban American Writers of the Second Generation, edited by Iraida H. López and Eliana S. Rivero. SUNY Press, 2019, pp. 93-105.

Hirsch, Marianne. "The Generation of Postmemory." Poetics Today, vol. 29, no. 1, Spring 2008, pp. $103-128$.

-_- "Past Lives: Postmemories in Exile." Exile and Creativity: Signposts, Travelers, Outsiders, Backward Glances, edited by Susan Rubin Suleiman. Duke UP, 1996, pp. 418-446.

-_-. "Surviving Images: Holocaust Photographs and the Work of Postmemory." Yale Journal of Criticism, vol. 14 , no. 1, 2001, pp. 5-37.

Hirsch, Marianne, and Nancy K. Miller (eds). Rites of Return: Diaspora Poetics and the Politics of Memory. Columbia UP, 2011.

López, Iraida H. "Introduction: Looking Back While Forging Ahead." Let's Hear Their Voices: Cuban American Writers of the Second Generation, edited by Iraida H. López and Eliana S. Rivero. SUNY Press, 2019, pp. xi-xxviii.

Nuez, Iván de la. "Mariel en el extremo de la cultura." Encuentro de la Cultura Cubana, vol. 8/9, Spring/ Summer 1998, pp. 105-109.

Ojito, Mirta. Finding Mañana: A Memoir of a Cuban Exodus. Penguin, 2005.

Oksman, Tahneer. "Postmemory and the 'Fragments of a History We Cannot Take In." Women's Studies Quarterly, vol. 48, no. 1/2, Spring/Summer 2020, pp. 133-136. DOI: https://doi.org/10.1353/ wsq.2020.0027

Palacio, Derek. The Mortifications. Tim Duggan Books, 2016.

Rodríguez Milanés, Cecilia. Marielitos, Balseros and Other Exiles. Ig Publishing, 2009.

Rosales Herrera, Raúl. "Diasporic Postmemory, Mariel, and Chantel Acevedo's A Falling Star." Camino Real, vol. 9, no. 12, 2017, pp. 29-45.

--_. "Remembering and Imagining in Contemporary Mariel Writing: Postmemory and the Case of Cecilia Rodríguez Milanés." Caribe: Revista de Cultura y Literatura, vol. 13, no. 2, Winter 2010/2011, pp. 53-70.

Shemak, April. Asylum Speakers: Caribbean Refugees and Testimonial Discourse. Fordham UP, 2011. DOI: https://doi.org/10.1515/9780823237357

Spitzer, Leo. "Persistent Memory: Central European Refugees in an Andean Land." Exile and Creativity: Signposts, Travelers, Outsiders, Backward Glances, edited by Susan Rubin Suleiman. Duke UP, 1996, pp. 373-396. DOI: https://doi.org/10.1215/9780822379829-018

Terdiman, Richard. Present Past: Modernity and the Memory Crisis. Cornell UP, 1993. DOI: https://doi. org/10.7591/9781501717604

Thakkar, Sonali. "Reparative Remembering." Women's Studies Quarterly, vol. 48, no. 1/2, Spring/Summer 2020, pp. 137-140. DOI: https://doi.org/10.1353/wsq.2020.0000

van Alphen, Ernst. "Second-Generation Testimony, Transmission of Trauma, and Postmemory." Poetics Today, vol. 27, no. 2, Summer 2006, pp. 473-488. DOI: https://doi.org/10.1215/03335372-2005-015

Victoria, Carlos. "De Mariel a los balseros: breve historia de una insatisfacción." Encuentro de la Cultura Cubana, vol. 15, Winter 1999-2000, pp. 70-73. 
How to cite this article: Rosales Herrera, R 2021 Mariel in Contemporary Cuban-American Writing: The Power of Diasporic Postmemory. Anthurium, 17(2): 9, 1-16. DOI: https://doi.org/10.33596/anth.443

Published: 14 December 2021

Copyright: (c) 2021 The Author(s). This is an open-access article distributed under the terms of the Creative Commons Attribution 4.0 International License (CC-BY 4.0), which permits unrestricted use, distribution, and reproduction in any medium, provided the original author and source are credited. See http://creativecommons.org/licenses/by/4.0/. 